IHTIYATH Jurnal Manajemen Keuangan Syariah

Vol. 4 No. 1, September 2020

\title{
PENYELESAIAN PEMBIAYAAN BERMASALAH PADA PEMBIAYAAN MURABAHAH DI BANK ACEH SYARIAH TAKENGON
}

\author{
Syaripuddin $^{1}$
}

\begin{abstract}
Abstrak
Penelitian ini bertujuan untuk mengetahui bagaimana penyelesaian pembiayaan bermasalah pada pembiayaan murabahah di bank aceh syariah takengon. Dalam penelitian ini penulis menggunakan data primer dan sekunder hasil wawancara yang dilakukan dengan pihak bank yang berkaitan dengan pembiayaan. Tujuan dari pada penelitian ini (1) untuk mengetahui bagaimana cara penyelesaian pembiayaan bermasalah pada pembiayaan murabahah pada bank aceh syariah (2) untuk mengetahui apa yang dilakukan pihak bank bagi nasabah yang tidak mampu membayar angsuran. Jenis penelitian ini adalah deskriptif kualitatif, dengan teknik pengumpulan data menggunakan wawancara, dokumentasi dan observasi. Informasi pada penelitian ini adalah pegawai dan nasabah bank aceh syariah takengon. Adapun hasil dari pada penelitian ini adalah cara untuk menyelesaikan pembiayaan bermasalah atau untuk penyelamat terhadap pembiayaan bermasalah yaitu dengan cara yang pertama dengan cara Rescheduling suatu tindakan yang diambil cara memperpanjang jangka waktu pembiayaan nasabah, dimana nasabah diberikan keringanan oleh pihak bank agar dapat melunasi kewajibannya. Yang kedua dengan cara Reconditioning Merupakan upaya lembaga keuangan dalam menyelamatkan pembiayaan dengan mengubah seluruh atau sebagai perjanjian yang telah dibuat oleh lembaga keuangan dangan nasabah, karena nasabah tidak mampu lagi membayar angsurannya. Dan yang terakhir yaitu Penyitaan Jaminan. Penyitaan jaminan ini merupakan jalan terakhir bagi pihak bank untuk menyelasaikan pembiayaan bermasalah apabila nasabah benar-benar tidak mempunya iktikad baik dalam melunasi kewajibannya atau memang nasabah tidak mampu lagi membayar semua hutang-hutangnya kepada pihak bank.
\end{abstract}

Kata Kunci : Bank Aceh Syariah, Pembiayaan Bermasalah.

\footnotetext{
${ }^{1}$ Mahasiswa Program Doktoral Ekonomi Syariah UIN Sumatera Utara/ syaripuddinsyarip6569@gmail.com
} 


\section{PENDAHULUAN}

Bank bagi masyarakat yang hidup di negara maju seperti negara- negara di Eropa, Amerika, dan Jepang, sudah merupakan suatu kebutuhan dasar yang harus dipenuhi. Bank merupakan mitra dalam rangka memenuhi semua kebutuhan keuangan meraka sehari-hari. Bank dijadikan sebagai tempat untuk melakukan berbagai transaksi yang berhubungan dengan keuangan seperti tempat mengamankan uang, melakukan investasi, pengiriman uang, melakukan pembayaran, atau melakukan penagihan (Kasmir, 2013).

Bagi suatu negara, Bank dapat dikatakan sebagai darahnya perekonomian suatu negara. Karena itu, peranan perbankan sangat memengaruhi kegiatan ekonomi suatu negara. Dengan kata lain, kemajuan bank disuatu negara dapat pula dijadikan ukuran kemajuan negara yang bersangkutan. Semakin maju suatu negara, maka semakin besar peranan perbankan dalam mengendalikan negara tersebut. Artinya, keberadaan dunia perbankan semakin dibutuhkan pemerintah dan masyarakat (Kasmir, Pemasaran Bank, 2010)

Sacara sederhana Bank diartikan sebagai lembaga keuangan yang kegiatan usahanya adalah menghimpun dana dari masyarakat dan menyalurkannya kembali kepada masyarakat serta memberikan jasa-jasa bank lainnya. Sedangkan pengertian lembaga keuangan adalah setiap perusahaan yang bergarak dibidang keuangan dimana kegiatannya, apakah hanya menghimpun dana atau hanya menyalurkan dana atau kedua-duanya (Kasmir, Pemasaran Bank, 2010)

Perbankan adalah segala sesuatau yang menyangkut dengan Bank, perbedaan yang sangat mendasar sekali antara Bank syariah dengan konvensional adalah. Pertama, Bank syariah berdasarkan bagi hasil dan margin keuntungan, sedangkan konvensional memakai perangkat bunga. Kedua, bank syariah melakukan investasi yang halal saja, sehingga Bank konvensional bisa halal, syubhat dan haram. Keempat, bank syariah berorientasi keuntungan duniawi dan ukhrawi. Sedangkan orientasi bank konvensional semata duniawi saja. Kelima, Bank syariah tidak melakukan spekulasi mata uang asing dalam operasionalnya untuk meraup keuntungan. Sedangkan Bank konvensional masih banyak yang melakukan (Antonio Syafi'i, 2001)

Bank Aceh Syariah adalah sebuah lembaga keuangan yang beroperasi sesuai dengan prinsip syariah (Al-qur'an dan Hadist), Bank Aceh syariah yang berfungsi sebagai sarana untuk memudahkan nasabah dan melancarkan aktivitas nasabah seperti penarikan, penyetoran, pembelian pulsa serta transaksi lainnya, Bank Aceh syariah pembantu Aceh Tengah memberikan penawarkan berbagai macam produk-produk yang dapat diterima dengan mudah oleh nasabah serta dapat dimanfaati oleh masyarakat luas yang lengkap dengan fasilitas untuk kenyaman dan kemudahan nasabah, keberadaan bank syariah disamping bank konvensional saat ini dinilai sebagai persaingan kerena 
mereka sama-sama mengeluarkan produk-produk yang sama namun berbeda dalam segi sistem maupun bagi hasil dan adminitrasinya.

Produk-produk yang ditawarkan oleh Bank Aceh syariah pembantu Aceh Tengah meliputi produk penghimpun dana seperti produk tabungan firdaus, tabungan simpeda, tabungan haji, tabungan seulaga, tabungan aneka guna, tabungan pensiun, tabungan sahara dan tabungan simple yang dikhususkan hanya kepada anak sekolah, dari produkproduk diatas memiliki keunggulan masingmasing, adapun produk-produk pembiayaan adalah pembiayaan qardhu hasan, pembiayaan musyarakah, pembiayaan mudharabah, pembiayaan wakalah dan pembiayaan murabahah yang sering di gunakan oleh PNS untuk pembiayaan komsumtif.

Adapun resiko ataupun masalah yang dihadapi oleh Bank Aceh Syariah pembantu Aceh Tengah yaitu pada bagian pembiayaan dimana nasabah yang mengambil pembiayaan beraneka ragam ada yang untuk keperluan komsumtif misalnya seperti pegawai negeri sipil yang kebutuhannya hanya untuk keperluan sehari-hari saja dan ada yang untuk modal kerja atau investasi dimana nasabah mengelola dana tersebut sesuai dengan prinsip syariah tidak boleh bertentangan dengan prinsip syariah. pembiayaan bermasalah banyak terjadi di pembiayaan modal kerja dimana nasabah tidak mampu membayar angsuran perbulan dikarenakan turunnya penghasilan atau penjualan nasabah maka sinasabah tidak mampu membayar kewajibabnnya kepada pihak Bank Aceh Syariah, maka nasabah jatuh pada kolekbilitas tiga empat dan lima dimana dapat menurunkan mutu pembiayaan dan menimbulkan kerugian bagi Bank.

Pembiayaan juga merupakan aktivitas Bank syariah dalam menyalurkan dana kepada pihak lain. Penyaluran dana dalam bentuk pembiayaan didasarkan kepada kepercayaan yang diberikan oleh pemilik dana. Pemilik dana percaya kepada penerima dana bahwa dana dalam bentuk pembiayaan yang diberikan pasti akan dibayar. Penerima pembiayaan mendapatkan kepercayaan dari pemberi pembiayaan, sehingga penerima pembiayaan berkewajiban untuk mengembalikan pembiayaan yang telah diterimanya sesuai dengan jangka waktu yang telah diperjanjikan dalam akad pembiayaan (Ismail, 2011)

Murabahah adalah istilah dari fikih islam yang berarti suatu bentuk jual beli tertentu ketika penjual menyatakan biaya perolehan barang, meliputi harga barang dan biaya-biaya yang dikeluarkan untuk memperoleh barang tersebut, dan tingkat keuntungan (margin) yang disepakati, Tingkat keuntungan bisa dalam bentuk lumpsum atau presentase tertentu dari biaya perolehan. Pembayaran bisa dilakukan secara spot (tunai) atau bisa dilakukan dikemudian hari yang disepakati bersama. Oleh karena itu, murabahah tidak dengan sendirinya mengandung konsep pembayaran tertunda, seperti yang secara umum dipahami oleh sebagian orang yang mengetahui murabahah syariah, tetapi tidak memahami fikih Islam (Ascarya, 2013)

Pembiayaan Murabahah merupakan jenis pembiayaan yang sering diaplikasikan dalam bank syariah, yang pada umumnya digunakan dalam transaksi jual beli barang 
investasi dan barang-barang yang diperlukan oleh individudalam pembiayaan ini Bank sebagai pemilik dana membelikan barang sesuai dengan spesifikasi yang diinginkan oleh nasabah yang membutuhkan pembiayaan, kemudian menjual kepada nasabah tersebut dengan menambah tetap. Sementara itu, nasabah akan mengembalikan keuntungannya dikemudian hari secara tunai maupun cicil.

Dalam mengelola dana nasabahnya pada pembiayaan murabahah, bank syariah dituntut untuk bersikap kehati-hatian sebagaimana ditetapkan dalam pasal 35 UU No. 21 Tahun 2008. Hal ini telah dijabarkan kembali pada visi pengembang perbankan syariah yaitu terwujudnya sistem perbankan syariah yang kompetitif, efisien, dan memenuhi prinsip-prinsip kehatian-hatian serta mampu mendukung sektor rill secara nyata melalui kegiatan pembiayaan berbasis bagi hasil dan transaksi rill dalam kerangka keadilan, tolong menolong, dan menuju kebaikan guna mencapai kemaslahatan masyarakat (Muhammad, 2014)

Produk Murabahah secara umum ditetapkan melalui mekanisme jual beli barang secara cicilan dengan penambahan margin keuntungan bagi Bank. Dari data yang didapatkan porsi pembiayaan dengan akad murabahah saat ini berkontribusi $58 \%$ dari total pembiayaan perbankan syariah Indonesia. Produk murabahah sebagai satu upaya standarisasi produk perbankan yang dilakukan OJK bekerjasama dengan pelaku industri dan Dewan Pengawasan Syariah Nasional serta nara sumber lainnya. Produk murabahah merupakan produk pembiayaan yang menggunakan akad murabahah salah satu dalam berbagai aktivitas pembiayaan perbankan syariah (Ismail, Perbankan Syariah, 2011)

Sebagai salah satu lembaga keuangan syariah, Bank Aceh Syariah memiliki sumber pembiayaan yaitu pembiayaan murabahah yang bertujuan untuk meningkatkan perekonomian masyarakat dalam menjalankan usahanya. Persyaratan pembiayaan yang sangat mudah dengan prosedur sederhana yang dapat mendorong masyarakat yang membutuhkan dana untuk memilih lembaga keuangan tersebut, pihak pembiayaan harus memberikan perhatian terhadap prosedur pengelolaan pembiayaan agar yang diberi dapat diterima dan dikembangkan sesuai dengan prinsip syariah oleh nasabah.

Murabahah akan sangat berguna sekali bagi seseorang yang membutuhkan barang secara mendesak tetapi kekurangan dana pada saat itu disebut kekurangan likuiditas, ia meminta pada bank agar membiayai pembelian barang tersebut dan bersedia menebusnya pada saat jatuh tempo (Kasmir, Bank dan Lembaga Keuangan Lainnya, 2014)

Bank merupakan lembaga keuangan yang beroperasi dalam bidang keuangan dan jasa. Perbankan syariah mempunyai tiga fungsi utama (1) menghimpun dana (2) menyalurkan dana (3) memberikan jasa bank lainnya. (Ali, 2008) Bank syariah juga dapat diartikan bahwa suatu lembaga keuangan atau perbankan yang menjalankan aktivitas kegiatan usahanya dan produk yang ditawarkan kepada nasabah sersumber dari 
Al-quran dan Hadits Nabi SAW. Bank syariah menjalankan bisnisnya yang berpedoman kepada ketentuan yang telah ditetapkan dalam Al-quran dan hadits.

Selanjutnya bank yang beroperasi sesuai dengan prinsip syariah Islam adalah lembaga keuangan yang dalam menjalankan usahanya mengikuti petunjukpetunjuk yang telah dituangkan dalam ketentuan syariah. (Rukman, 2010) Yang paling populer yang digunakan oleh lembaga keuangan dalam hal ini perbankan syariah adalah model jualbeli murabahah. murabahah berarti suatu penjualan barang seharga barang tersebut ditambah keuntungan yang disepakati.

Bank syariah yang didesain dengan model bagi hasil dalam menjalankan suatu bisnis atau usaha dimana untuk terbinanya dalam mengangung risiko antara pemilik dana yang menitipkan dananya di lembaga keuangan dan lembaga keuangan sebagai pengelola dana dan masyarakat yang membutuhkan dana dengan status pinjam atau mengelola usaha. Para pengelola menyetujui akad-akad yang sesuai dengan akad muamalah (Rukmana, 2010). Di sisi lain akad mengikat kedua belah pihak yang melakukan akad yang telah disepakati di awal, dan masing-masing melaksanakan akad yang telah disepakati tersebut, bila dikemudian hari kesepakatan tersebut tidak dijalankan dengan baik dan semestinya maka akan menerima sanksi yang telah disepakati di awal. Murabahah merupakan transaksi jual beli barang antara bank dengan nasabah. Atau dengan kata lain jasa pembiayaan dengan bentuk transaksi jual beli dengan cara cicilan.

Kalau kita lihat pembiayaan dalam sekala makro yaitu financing atau pembelanjaan adalah pembiayaan yang dikeluarkan untuk tujuan dalam skala yang lebih besar dengan tujuan untuk mengerakan investasi yang telah mempunyai plening dengan lebih baik dan diterapkan sendiri maupun oleh orang lain. Kalau kita lihat secara mikro, pembiayaan diperuntukkan dalam hal pemodalan yang dilaksanakan oleh suatu lembaga pembiayaan, yang terdiri dari bank syariah sebagai penyalurnya kepada konsumen sebagai nasabahnya. (Arif, 2012) Atau dengan pengertian yang lain pembiayaan adalah penyalur modal tagihan yang terdiri dari : (1) transaksi dengan bentuk mudharabah dan musyarakah (2) transaksi yang menawarkan dalam bentuk ijarah atau sewa beli dalam bentuk ijarah muntahiya bitamlik (3) transaksi dalam bentuk fiutang mudharabah, salam dan istishna. (Wangsawidjaja, 2010)

Pembiayaan terdiri dari dua macam yang pertama (1) pembiayaan produktif yaitu pembiayaan yang ditunjukkan guna untuk kebutuhan dalam produksi dalam arti luas yaitu untuk mengerakkan roda usaha baik usaha produksi, perdagangan, maupun investasi. (2) pembiayaan konsumtif adalah modal yang diberikan guna untuk memenuhi kebutuhan konsumtif yang akan habis digunakan untuk memenuhi kebutuhan (Antonio, 2001)

Pembiayaan sumber pendapatan yang paling besar bagi lembaga keuangan dalam hal ini adalah bank syariah. Salah satu model pembiayaan perbankan yang berlandaskan 
IHTIYATH Jurnal Manajemen Keuangan Syariah

Vol. 4 No. 1, September 2020

prinsip syariah adalah murabahah yaitu terjadinya jual beli barang dengan harga awal dengan tambahan keuntungan disepakati kedua belah pihak. (Soemitra, 2010)

Dalam pembiayaan memiliki dasar hukumnya yaitu dalam surah An-Nisa ayat 29 yang berbunyi

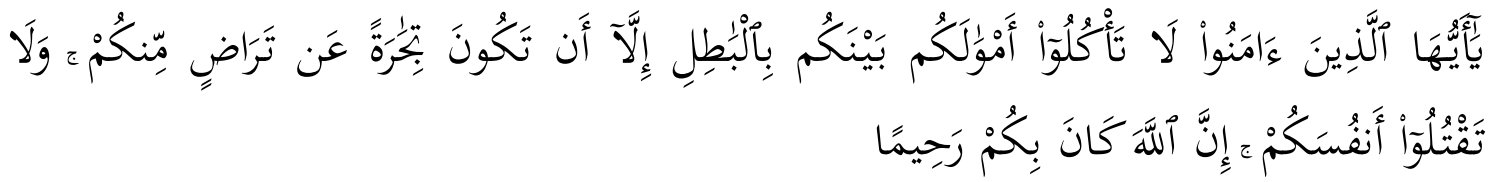

Artinya: Hai orang-orang yang beriman, janganlah kamu saling memakan harta sesamamu dengan jalan yang batil, kecuali dengan jalan perniagaan yang Berlaku dengan suka sama-suka di antara kamu. dan janganlah kamu membunuh dirimu Sesungguhnya Allah adalah Maha Penyayang kepadamu.

Dan Allah juga berfirman dalam surah Al-Baqarah ayat 280 yang berbunyi

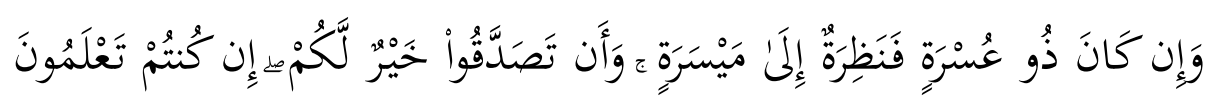

Artinya: Dan jika (orang yang berhutang itu) dalam kesukaran, Maka berilah tangguh sampai Dia berkelapangan. dan menyedekahkan (sebagian atau semua utang) itu, lebih baik bagimu, jika kamu mengetahui.

\section{METODE PENELITIAN}

Metode yang dipakai dalam penulisan ini merupakan metode desktiptif kualitatif. Metode desktiptif kualitatif yaitu menganalisis, mengambarkan, dan meringkas berbagai kondisi, situasi dari berbagai data yang dikumpulkan berupa hasil wawancara atau pengamatan mengenai masalah yang diteliti yang terjadi dilapangan (Winartha, 2006).

Teknik pengumpulan data dalam penelitian ini yaitu wawancara, dokumentasi, dan observasi. (1) pengumpulan data merupakan kegiatan yang penting dalam penelitian dalam penelitian ini mengunakan wawancara dengan mengajukan pertanyaan langsung oleh pewawancara kepada responden. Dalam penelitian ini dimaksudkan untuk mendapatkan informasi secara lengkap dan komprehensif sesuai dengan tujuan penelitian. Pada penelitian ini peneliti mewawancarai bapak Attaillah sebagai pimpinan Bank Aceh Takengon, (2) Dokumentasi dilakukan mengambil data-data yang diperlukan dalam penelitian ini. Yang terdiri dari data-data yang diperuntukkan mengenai gambaran umum objek penelitian yaitu yang terdiri dari sejarah, produk dan brosur persyaratan pelaksanaan produk-produk Bank Aceh Takengon. (3) pengumpulan data dilakukan dengan cara observasi untuk mengamati langsung responden yang ada di lapangan atau lokasi penelitian untuk memperoleh gambaran dan berbagai data konkrit secara langsung di lapangan atau tempat penelitian. Penelitian akan mengamati langsung kegiatan yang berkaitan dengan pembiayaan murabahah dari Bank Aceh Syariah Takengon. 


\section{HASIL DAN PEMBAHASAN}

Bank Aceh Syariah pada umunya memiliki kendala atau masalah dalam pembiayaan, pada pembiayaan murabahah bermasalah adalah suatu keadaan dimana nasabah sudah tidak sanggup untuk membayar sebagian atau seluruh dari kewajibannya kepada pihakBank Aceh Syariah Aceh Tengah sebagaimana yang telah disetujui pada saat sebelum pengambilan pembiayaan sesuai dengan janji di dalam akad.

Dalam pasal 9 PBI No.8/21/PBI/2006, terdapat 5 (lima) golongan mengenai kualitas pembiayaan yaitu sebagai berikut:

a. Lancar

Dapat dikatakan lancar apabila nasabah dapat memenuhi kriteria sebagai berikut:

1) Pembayaran angsuran pokok tepat waktu dan / bagi hasil

2) Memiliki rekening yang aktif

3) Bagian dari pembiayaan yang dijamin dengan anggunan tunai

b. Dalam perhatian khusus, kriterianya yaitu sebagai berikut:

1) Terdapat tunggakan angsuran pokok dan/ bagi hasil yang belum melampaui sembilan bulan

2) Mungkin terjadinya cerukan

3) Mutasi rekening relatif aktif

4) Jaringan terjadi pelanggaran terhadap kontrak yang diperjanjikan

5) Didukung oleh pinjaman baru

c. Kurang lancar, memiliki kriteria sebagai berikut:

1) Sering terjadinya cerukan

2) Terdapat tunggakan angsuran pokok/bagi hasil

3) Frekuensi mutasi rekening relatif rendah

4) Terdapat indikasi masalah keuangan yang dihadapi debitur

5) Terjadinya pelanggaran terhadap kontrak yang telah diperjanjikan

6) Dokumentasi pinjaman lemah

d. Diragukan, memiliki kriteria sebagai berikut:

1) Terdapat cerukan yang bersifat permanen

2) Terdapat wanprestasi lebih dari 180 hari

3) Terdapat anggsuran pokok dan/ bagi hasil 
IHTIYATH Jurnal Manajemen Keuangan Syariah

Vol. 4 No. 1, September 2020

4) Dokumentasi hukum yang lemah baik untuk perjanjian pembiayaan mauoun pengikat jaminan

e. Macet, memiliki kriteria sebagai berikut:

1) Terdapat tunggakan pokok/ bagi hasil

2) Kerugian operasional ditutup dengan pinjaman baru

3) Dari segi hukum maupun kondisi pasar, jaminan tidak dapat dicairkan pada nilai wajar

Untuk keperluan penghapusan Bank diharuskan untuk membentuk cadangan Penyelisihan Penghapusan Aktiva Produktif (PPAP) sebagai berikut:

a. Bank wajib membentuk cadangan $1 \%$ dari seluruh pembiayaan

b. Cadangan $3 \%$ dari pembiayaan yang tergolong tidak lancer setelah dikurangi nilai agungan yang telah dikuasai)

c. Cadangan $50 \%$ dari pembiayaan yang tergolong diragukan (setelah dikurangi nilai agunan)

d. Cadangan $100 \%$ dari pembiayaan yang tergolong macet (setelah dikurangin nilai agunan yang dikuasi)

Adapun cara penanganan yang dilakukan oleh Bank Aceh Syariah untuk menyelesaikan pembiayaan bermasalah pada pembiayaan murabahah adalah sebagai berikut:

a. Preventif (pencegahan)

1) Pemahaman dan pelaksanaan proses pembiayaan yang benar meyangkut dengan internal dan eksternal.

2) Pemantauan dan pembinaan pembiayaan (on site dan on desk monitoring).

3) Memahami faktor yang menjadi penyebab dan gejala dini pembiayaan bermasalah

b. Kuratif (penyelesaian)

Account officer melakukan analisis atau evaluasi mengenai aspek (manajemen, pemasaran, produktif, keuangan, yuridis, agunan), ada beberapa cara yang dapat dilakukan Bank Aceh untuk menyelesaikan pembiayaan bermasalah. Namun sebelum dilaksanakan restrukturisasi pembiayaan ada baiknya Bank Aceh Syariah untuk mengamati sejauh ini apakah nasabah pembiayaan yang bermasalah mempunyai ikhtikat baik untuk membayar hutang atau tidak, ada beberapa indikator yang dapat digunakan untuk melihat ikhtikat baik nasabah pembiayaan bermasalah yaitu dengan cara sebagai berikut:

1) Setelah pembiayaan macet nasabah tidak sulit dihubungi atau menghidar bila pihak Bank datang kerumahnya. 
2) Apabila sebelum pembiayaan bermasalah nasabah selalu kooperatif terhadap bank dan mau menjalankan segala kewajibannya untuk mencicil pokok dan bagi hasil.

c. Tahapan penyelesaian melalui Restrukturisasi

Tahap ini dilakukan oleh Bank Aceh Syariah pembantu Aceh Tengah apabila terjadi suatu pembiayaan yang bermasalah apabila sudah termasuk kepada kolekbilitas yang ke 5 yaitu macet. Adapun tahapan tersbut adalah sebagai berikut:

1) Rescheduling (penjadwalan kembali)

Penjadwalan ulang dapat dilakukan dengan mengubah jangka waktu pembiayaan dan jumlah angsuran. Rescheduling yang dilakukan dengan memperpanjang jangka waktu jatuh tempo pembiayaan tanpa mengubah sisa kewajiban nasabah yang harus dibayarkan kepada bank syariah (Syamsuddin, 2012).

2) Reconditioning (persyarataan kembali)

Persyaratan kembali yang dilakukan dengan menetapkan kembali syaratsyarat pembiayaan antara lain nisbah bagi hasil, jumlah angsuran, jangka waktu jatuh tempo, jadwal pembayaran, pemberian potongan pokok dan untuk lainnya tanpa menambah sisa kewajiban nasabah yang harus dibayarkan kepada pihak Bank Aceh Syariah pembantu Aceh Tengah.

d. Penyelesaian melalui Penjualan atau Pelelangan Agunan

Jaminan Penyelesaian melalui penjualan agunan adalah yang terakhir yang dilakukan pihak Bank Aceh Syariah pembantu Aceh Tengah terhadap nasabahnasabahnya yang terkait dengan pembiayaan bermasalah, Pastinya Bank sudah melakukan cara-cara yang diatas agar nasabah membayar hutang atau kewajibannya akan tetapi nasabah masih belum sanggup untuk melunasi hutang atau kewajibannya kepada Bank Aceh Syariah pembantu Aceh Tengah.

\section{KESIMPULAN}

Adapun cara untuk menyelesaiakan pembiayaan bermasalah atau untuk penyelamat terhadap pembiayaan bermasalah yaitu dengan cara, yang pertama dengan cara rescheduling suatu tindakan yang diambil cara memperpanjang jangka waktu pembiayaan nasabah, dimana nasabah diberikan keringanan oleh pihak bank agar dapat melunasi kewajibannya. Yang kedua dengan cara reconditioning merupakan upaya lembaga keuangan dalam menyelamatkan pembiayaan dengan mengubah seluruh atau sebagai perjanjian yang telah dibuat oleh lembaga keuangan dangan nasabah, karena nasabah tidak mampu lagi membayar angsurannya. Dan yang terakhir yaitu penyitaan jaminan ini merupakan jalan terakhir bagi pihak bank untuk menyelasaikan pembiayaan bermasalah apabila nasabah benar-benar tidak mempunya iktikad baik dalam melunasi kewajibannya atau memang nasabah tidak mampu lagi membayar semua hutanghutangnya kepada pihak bank. 
IHTIYATH Jurnal Manajemen Keuangan Syariah

Vol. 4 No. 1, September 2020

\section{DAFTAR PUSTAKA}

Akte Bank Aceh Syariah No. 2 tanggal 4 Juni 2015

Antonio Syafi'i, Muhammad, 2001. Bank Syariah: Dari Teori Dan Praktik, Jakarta: Gema Insani.

Ascarya, 2013. Akad dan Produk Bank Syariah, Jakarta: PT. Raja Grafindo Persada.

Djuwaini, Dimyauddin. 2008. Pengantar Fiqh Muamalah, Yogyakarta: CelebsnTimur UH III.

Fitriyana, Eka. 2015. Asas-asas Perbankan Islam dan Lembaga-lembaga Terkait (BMUI, Takaful dan Pasar Modal Syariah di Indonesia), Jakarta: PT. Raja Grafindo Persada.

Hakim, Lukman. 2012. Prinsip-Prinsip Ekonomi Islam. Yogyakarta: Erlangga.

Hasibuan, Malayu. 2002.Dasar-Dasar Perbankan. Jakarta: BumiAksara.

Ismail. 2011. Perbankan Syariah, Jakarta: Kencana.

Kasmir. 2010. Pemasaran Bank, Jakarta: Kencana.

Kasmir. 2013. Dasar-Dasar Perbankan, Jakarta: Rajawali Pers.

Maulana, Muhammad, 2014. Sistem Jaminan Dalam Pembiayaan Pada Perbankan Syariah Menurut Hukum Islam, Banda Aceh: Ar-Raniry Press.

Nurdin, Ridwan. 2010. Perbankan Syariah Di Indonesia (Sejarah, Konsep, Dan Perkembangannya), Banda Aceh: PeNa.

PT. Bank Aceh Syariah Cabang Bener Meriah 2018 1, "Brosur Tabungan Firdaus”

PT. Bank Aceh Syariah Cabang Bener Meriah 2018 3, "Brosur Tabungan Haji”

PT. Bank Aceh Syariah Cabang BenerMeriah 2018 2,"Brosur Tabungan Seulanga” 